University of Nebraska - Lincoln

DigitalCommons@University of Nebraska - Lincoln

USDA National Wildlife Research Center - Staff Publications
U.S. Department of Agriculture: Animal and Plant Health Inspection Service

2018

\title{
Post-fledging movement and spatial ecology of the endangered Cape Vulture (Gyps coprotheres)
}

\author{
Francis R. Martens \\ Nelson Mandela University \\ Morgan B. Pfeiffer \\ Nelson Mandela University \\ Colleen T. Downs \\ University of KwaZulu-Natal
}

Jan A. Venter

Nelson Mandela University, jan.venter@mandela.ac.za

Follow this and additional works at: https://digitalcommons.unl.edu/icwdm_usdanwrc

Part of the Life Sciences Commons

Martens, Francis R.; Pfeiffer, Morgan B.; Downs, Colleen T.; and Venter, Jan A., "Post-fledging movement and spatial ecology of the endangered Cape Vulture (Gyps coprotheres)" (2018). USDA National Wildlife Research Center - Staff Publications. 2147.

https://digitalcommons.unl.edu/icwdm_usdanwrc/2147

This Article is brought to you for free and open access by the U.S. Department of Agriculture: Animal and Plant Health Inspection Service at DigitalCommons@University of Nebraska - Lincoln. It has been accepted for inclusion in USDA National Wildlife Research Center - Staff Publications by an authorized administrator of DigitalCommons@University of Nebraska - Lincoln. 


\title{
Post-fledging movement and spatial ecology of the endangered Cape Vulture (Gyps coprotheres)
}

\author{
Francis R. Martens ${ }^{1} \cdot$ Morgan B. Pfeiffer $^{1,2,3} \cdot$ Colleen T. Downs $^{3} \cdot$ Jan A. Venter $^{1}$ (D)
}

Received: 12 October 2017 / Revised: 19 April 2018 / Accepted: 10 May 2018

(c) Dt. Ornithologen-Gesellschaft e.V. 2018

\begin{abstract}
The post-fledging dependence period (PFDP) is one of the most critical stages in the life history of some avian species. Birds are particularly sensitive to mortality during this stage as they must learn essential skills, such as efficient locomotion, proficient food location and predator avoidance. Knowledge of the PFDP would provide valuable information for conservation management of endangered species, many of which experience high juvenile fatality rates. Post-fledging movements of five endangered Cape Vultures were recorded using Global Positioning System/Global System for Mobile communication telemetry in South Africa. Home range sizes, distances travelled from the nest and habitat use were determined over 11 months during the PFDP. Fledglings increased their home range progressively for the first 2 months, then exhibited a rapid increase in home range size associated with dispersal from their natal colony. Maximum net daily distance also rapidly increased following the dispersal period. A preference for protected areas and woody vegetation (representing cliff faces used for roosting) in terms of habitat use for foraging was evident. The knowledge of the movement and habitat use of juvenile Cape Vultures can aid in the effective conservation planning for the species. Conservation programs in identified areas can be focused on power line and wind-farm mitigation, areas of supplementary feeding and anti-poisoning events.
\end{abstract}

Keywords Post-fledging dependence period $\cdot$ Home range $\cdot$ Habitat use $\cdot$ Dispersal $\cdot$ Juvenile fatality

\section{Zusammenfassung}

Orstbewegungen nach dem Flüggewerden und die räumliche Ökologie des bedrohten Kapgeiers (Gyps coprotheres) Die Zeit direkt nach dem Flüggewerden ist einer der kritischsten Abschnitte im Leben einer Vogelart. In dem Stadium ist die Sterblichkeitsrate der Vögel besonders hoch, da sie in dann ganz wesentliche Fähigkeiten wie z.B. die effiziente Fortbewegung, das geschickte Auffinden von Nahrung sowie das Vermeiden von Feinden erlernen müssen. Genaueres Wissen über diesen Lebensabschnitt böte dem Management für den Schutz bedrohter Arten wertvolle Informationen, da viele dieser Arten in ihrer juvenilen Lebensphase eine hohe Sterblichkeitsrate aufweisen. Für fünf gefährdete Kapgeier zeichneten wir in Südafrika nach dem Flüggewerden die Ortsbewegungen mittels GPS/GSM-Telemetrie auf. Über elf Monate hinweg wurde während dieser Lebensphase ihr Aktionsradius, die Strecken zwischen Nest und genutztem Habitat, aufgezeichnet. In den ersten beiden Monaten erweiterten die flüggen Jungtiere kontinuierlich ihren Aktionsradius; dann vergrößerten sie ihn rapide, verbunden mit der Ausbreitung weg von ihrer Brutkolonie. Im Verlauf dieser Ausbreitung vergrößerte sich rasch auch die maximale tägliche Entfernung von der Kolonie. Bei der Nahrungssuche zeigten sie eine klare Präferenz für Naturschutzgebiete und für Gehölzvegetation (mit steilen Felswänden zum Übernachten). Genauere Informationen über die Ortsbewegungen und Habitatnutzung junger Kapgeier kann bei der Planung effektiver Schutzmaßnahmen für diese Art helfen. Programme zu ihrem Schutz können sich in ausgewiesenen Gebieten auf die Entschärfung von Hochspannungsleitungen und Windkraftanlagen konzentrieren sowie auf Gebiete für zusätzliche Fütterung und die Bekämpfung des Auslegens von Giftködern.

Communicated by N. Chernetsov.

Electronic supplementary material The online version of this article (https://doi.org/10.1007/s10336-018-1564-x) contains supplementary material, which is available to authorized users.

Extended author information available on the last page of the article

\section{Introduction}

With an ever-increasing human population, and its associate infrastructure, anthropogenic threats are becoming a foremost concern to many wildlife species, particularly 
birds (Loss et al. 2015; Pfeiffer et al. 2015a). Environmental conditions, resource availability, age, and breeding status at which a species uses its environment influence its fitness (Johnson 2007; Morrison and Wood 2009). Large raptor populations are sensitive to adult mortalities; however, high juvenile mortality rates also affect the population (Yamaç and Bilgin 2012). High mortality rates of juvenile raptors are associated with inexperience in basic fundamental tasks (adequate flight abilities; efficient resource location) and naïve individuals moving across an extensive, unfamiliar landscape (Yamaç and Bilgin 2012; Harel et al. 2016; Krüger et al. 2014). The post-fledging dependence period (PFDP), the time period between the first flight from the nest and the inception of dispersal, is one of the most critical stages in the life history of birds (López-López et al. 2014). During this time, fledged individuals must learn to become self-sufficient, gain flight skills and effectively locate food sources (Delgado et al. 2009a; López-López et al. 2014; Krüger and Amar 2017). Following the PFDP, juvenile raptor populations are often observed close to the natal area after which time they slowly start to 'drift' further away from the natal surrounds (López-López et al. 2014; Yamaç and Bilgin 2012; Krüger et al. 2014; Sandgren et al. 2014). It is speculated that this movement away from the natal colony may be a result of the improvement of flight abilities (Yamaç and Bilgin 2012; Krüger et al. 2014). Consequently, as flight ability improves with age, individuals are able to move longer distances, covering larger areas. Juvenile raptors often exhibit larger home ranges when compared to adults and this may be linked to the fact that juveniles are often outcompeted for resources by more competent adults (Yamaç and Bilgin 2012; Krüger et al. 2014). Secondly, juvenile birds are not philopatric and therefore do not have to return to the colony for breeding (Yamaç and Bilgin 2012; Krüger et al. 2014). During this dispersal phase when juveniles move across extensive, unfamiliar environments mortality rates are high given their inexperience of flight in unfamiliar terrain (Harel et al. 2016; Yamaç and Bilgin 2012).

Juveniles during their early life stages are said to suffer higher mortality rates than adults (Péron and Grémillet 2013), with mortality rates peaking during the first several months and, of the birds that fledge, nearly half are said to die within the first year (Wiens et al. 2006). Low survival rates of juveniles during the fledging period have been found in several studies, including those on Burrowing Owls (Athene cunicularia) in Alberta (45\% survival rate) and Saskatchewan (48\% survival) (Todd et al. 2003); Prairie falcon (Falco mexicanus) fledging survivorship is lower than during the egg and nestling period (McFadzen and Marzluff 1996); and Oriental White-backed Vultures (Gyps bengalenesis) fledging mortality exceeds that of adults and subadults (Gilbert et al. 2002). High fledging mortality for Gyps species is not uncommon, with Cape Vultures (Gyps coprotheres) estimated to have a survival rate of $17 \%$ during the first year, and only a $10.6 \%$ chance of reaching their third year (Piper et al. 1981). Gyps species and other Old World vultures are sensitive to higher mortality rates given their delayed maturity and low productivity (Ogada et al. 2012) and declines of vulture species may lead to breakdowns of vital ecosystem services and processes (Loss et al. 2015).

The Cape Vulture is a long-lived, obligate scavenger endemic to southern Africa (Mundy et al. 1992), currently listed on the International Union for Conservation of Nature's Red List as 'Endangered' (BirdLife International 2015). It has undergone a rapid decline of $66-81 \%$ over the past 50 years, and continues to drop in range size and numbers. The 2013 global population was estimated at approximately 4700 pairs (9400 mature individuals), of which Lesotho, Eastern Cape and KwaZulu-Natal Provinces (and marginal areas of the Free State and Swaziland) contain $42 \%$ of the breeding pairs (Allan 2015). Age influences foraging range and use of the environment in terms of spatial and temporal use (Piper et al. 1989). Mature birds are often tied to colonies and forage within a certain range around the colony, returning to the colony every night, and are thus considered central place foragers (Boshoff and Minnie 2011; Pfeiffer et al. 2015b). Foraging ranges are influenced by surrounding land use practices, and sparse and ephemerally distributed food sources (Phipps et al. 2013; Pfeiffer et al. 2015b; Kane et al. 2016). Colonies are often located in protected areas and use of such areas by adult birds is often highest during the breeding season, whilst farming area use (communal and private farmland) is prevalent during the non-breeding season (Pfeiffer et al. 2015b; Phipps et al. 2013). Breeding birds are spatially constricted in their foraging movement (40-60 km radius from the colony), so as to encounter potential opportunities for breeding and care of nestlings (Boshoff et al. 2010; Pfeiffer et al. 2015b; Phipps et al. 2013). Juveniles are restricted to the colony for the first few months, as a result of being exclusively or partially dependent on their parents for food, until the following breeding season starts, when parents stop providing food, and they disperse from the colony and travel throughout the subcontinent (Piper et al. 1981). Immature Cape Vultures have been shown to have far greater home ranges than adult Cape Vultures (Kane et al. 2016; Phipps et al. 2013).

Inexperienced flight combined with the lack of knowledge of the surrounding areas in fledged vulture individuals may expose them to a greater assortment of threats across an extensive landscape during their first years of exploration (Krüger et al. 2014; Harel et al. 2016; Krüger and Amar 2017). Detailed knowledge of juvenile PFDP may provide valuable information on the risks that fledglings face, and this is particularly important in the case of endangered species, which often face stochastic events during their exploratory PFDP (Delgado et al. 2009b). Thus, understanding how 
Cape Vultures use their environment during the PFDP and knowledge of the timing of dispersal can provide crucial information for conservation management of this long-lived, late-maturing endangered species.

The aim of the study was to determine the post-fledging movements and spatial ecology of juvenile Cape Vultures in South Africa. Home range of fledged individuals, time of natal dispersal, maximum net daily distance travelled, as well as habitat use of juveniles was determined. It was predicted that home range of fledged individuals would increase with age, natal dispersal would coincide with the subsequent breeding season for adult birds and habitat use would be similar to that of adults.

\section{Methods}

\section{Study site}

Colleywobbles Vulture Colony $\left(32^{\circ} 0^{\prime} \mathrm{S}, 28^{\circ} 35^{\prime}\right.$ E; Fig. 1) is situated along cliffs above the Mbashe River in the Idutywa District of the former Transkei, Eastern Cape Province, South Africa. It is an ancestral vulture colony, being in existence since at least the 1890s (BirdLife South Africa 2015). It is the largest colony in the Southern Node (which constitute the Eastern Cape and KwaZulu-Natal Provinces of South Africa together with Lesotho), supporting more than $4 \%$ (on average 200 breeding pairs) of the global population of Cape Vulture and is a 3100-ha globally important bird area (Important Bird and Biodiversity Area number SA088) (BirdLife South Africa 2015). The former Transkei, with its abundance of carrion as a result of higher livestock mortality rates, attributed to communal subsistence farming, provides an abundant food source (Vernon 1998; Pfeiffer et al. 2015a,b). Furthermore, competition from large predators may be insignificant as only two meso-carnivores persist in the area (Black-backed Jackal (Canis mesomelas) and Caracal (Caracal caracal)) (Brown and Piper 1988).

Eight nestlings from Colleywobbles Vulture Colony were fitted with Global Positioning System (GPS)/Global System for Mobile communication transmitters (Cellular Tracking Technologies, Rio Grande, NJ) in September 2015. Temporary extraction of nestlings from their nests was carried out by placing them in a secure bag and hoisting them to the top of the cliff. Each nestling was fitted with a transmitter (weighing on average $136 \mathrm{~g}$ ) attached as a pelvic mount, a metal SAFRING ring and a yellow patagial tag. Transmitters were set to record from sunrise to sunset at 15-min intervals. GPS locations of vultures, horizontal dilution of precision, fix quality, direction of travel, speed and altitude were recorded. Data were uploaded to the manufacturer's website when the unit had cellular coverage during the transmission time (Greenwich Mean Time +2). Of the eight transmitters deployed, only five recorded data once fitted to the birds. It is unknown why the transmitters failed, but a complete battery drain due to the nestlings remaining multiple months in the shade (batteries were charged with solar power) before fledging could have contributed to this problem. Of the three
Fig. 1 Location of the Colleywobbles and Msikaba Cape Vulture Colony in the Eastern Cape Province, South Africa

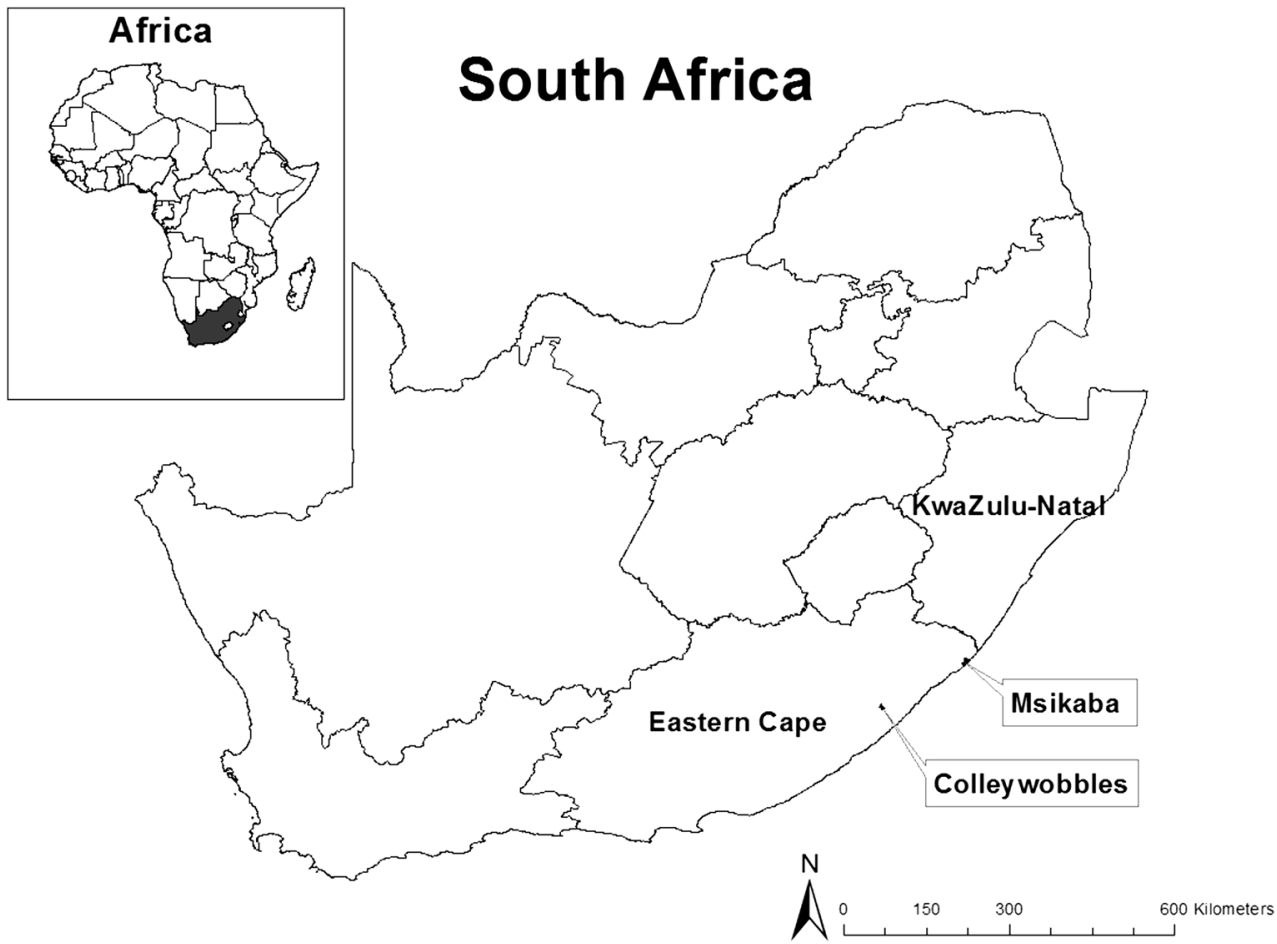


transmitters that did not transmit data, one bird was found dead below a power line (Ndalo; ring number G26716, wing tag X050), which confirmed the bird's dispersal, but GPS movements were not recorded. Mkhalolo (ring number G26707, wing tag X057), a second bird that did not transmit data, was spotted by a member of the public in December 2016, confirming the bird's dispersal (Pfeiffer et al. 2017). Of the remaining five functioning transmitters, two ceased transmitting after 11 months as the birds were found dead at the base of power lines.

Transmitter data were collected for 11 months post-fledging between November 2015 and November 2016 (a combined total of 55 bird-months; Table 1; 19,773 (mean $=3955$, $\mathrm{SD}=683$ ) GPS fixes in total; Table 2].

\section{Home range size}

GPS data were downloaded as a spreadsheet from the manufacturer's website and filtered for technical errors. GPS locations located in inaccurate Universal Transverse Mercator zones that had a poor quality fix (type of fix $<3$ ) were removed. Duplicate date and time stamps were also removed. Home range of each individual was determined by means of a fixed kernel density estimate (KDE) with a reference bandwidth (HRef) in the reproducible home range package (Signer and Balkenhol 2015) in R (Laver and Kelly 2008; R Core Team 2016). To eliminate potential bias in the approximation of space use as a result of individual variability, a random sample from the data set was selected and a Spearman's rank test was conducted to determine the correlation between the number of location fixes used for the $\mathrm{KDE}$ and the size of the home range.

The fixed 50\% KDE and 99\% KDE were calculated over each 14-day period. The 14-day period was considered the maximum time a fledgling could survive without aid from its parents (Mundy et al. 1992). Fifty percent KDE represented core areas utilised, whilst $99 \%$ KDE represented home range. Although home range is often determined at 95\% KDE, this generally produced fragmented and undersmoothed contours, and thus 99\% KDE was selected (Phipps et al. 2013; Pfeiffer et al. 2015b). Changes in fledging home range size in each 14-day period over 11 months (315 days) was explored using a general linear model, with Period as a continuous variable and Individual as a fixed effect. Statistical analyses were conducted in SPSS (IBM Corp 2016). The mean core area and home range of juvenile birds during the PFDP (this is prior to dispersal-see below) was also calculated.

\section{Dispersal distance}

To determine the range of Cape Vulture fledging movements each individual's maximum net daily distance from the nest was calculated. Maximum net daily distance from the nest to the furthest location for that day was calculated based on the straight-line distance (Signer and Balkenhol 2015). The

Table 1 Tracking details between September 2015 and November 2016 for five fledging Cape Vultures. Tracking of Lunguza and Sibane terminated when the birds were found dead below power lines

\begin{tabular}{llllllc}
\hline Identifier (ID) & Date tagged & Date fledged & Date tracking terminated & Dispersal date & $\begin{array}{l}\text { Post-fledging } \\
\text { dependence period } \\
\text { (days) }\end{array}$ & $\begin{array}{l}\text { Months } \\
\text { tracked }\end{array}$ \\
\hline Lunguza (X052) & 23 September 2015 & 11 December 2015 & 09 November 2016 & 07 April 2016 & 118 & 11 \\
Mbashe (X071) & 23 September 2015 & 16 December 2015 & 02 November 2016 & 20 February 2016 & 66 & 11 \\
Msikiti (X053) & 23 September 2015 & 31 December 2015 & 19 November 2016 & 02 May 2016 & 123 & 11 \\
Sibane (X056) & 24 September 2015 & 12 December 2015 & 06 November 2016 & 23 Apr 2016 & 133 & 23 \\
Xobo (X055) & 23 September 2015 & 21 December 2015 & 11 November 2016 & 23 Feb 2016 & 64 & 11 \\
\hline
\end{tabular}

Table 2 Total number of Global Positioning System $(G P S)$ fixes, average number of GPS fixes per day, home range sizes of $50 \%$ kernel density estimate (50\% KDE), 99\% KDE and the maximum net daily distance travelled from the nest by five fledging Cape Vultures 11 months post-fledging

\begin{tabular}{|c|c|c|c|c|c|}
\hline \multirow[t]{2}{*}{ ID } & \multirow[t]{2}{*}{ No. of GPS fixes } & \multirow{2}{*}{$\begin{array}{l}\text { No. of GPS } \\
\text { fixes per day }\end{array}$} & \multicolumn{2}{|c|}{ Home range $\left(\mathrm{km}^{2}\right)$} & \multirow{2}{*}{$\begin{array}{l}\text { Maximum net } \\
\text { daily distance } \\
(\mathrm{km})\end{array}$} \\
\hline & & & $50 \% \mathrm{KDE}$ & $99 \% \mathrm{KDE}$ & \\
\hline Lunguza (X052) & 3076 & 137 & 1005.81 & 6095.03 & 183 \\
\hline Mbashe (X071) & 4007 & 180 & 5326.03 & 29080.57 & 227 \\
\hline Msikiti (X053) & 4167 & 188 & 4522.43 & 23955.98 & 306 \\
\hline Sibane (X056) & 4918 & 221 & 2846.75 & 18976.32 & 192 \\
\hline Xobo (X055) & 3605 & 161 & 8689.52 & 48407.46 & 469 \\
\hline Mean & $3955 \pm$ & 177 & $4478.11 \pm$ & $25303.07 \pm$ & 275 \\
\hline$\pm \mathrm{SD}$ & 683 & 31 & 2879.89 & 15482.84 & 96.86 \\
\hline
\end{tabular}


first day an individual flew over $100 \mathrm{~m}$ was considered the date of fledging, commencing the PFDP.

Dispersal date from the nest was calculated using the fledgling's maximum net daily distance. The methods described in Weston et al. (2013) and Krüger and Amar (2017) were used to identify when the birds became independent of their natal colony. Five adult Cape Vultures home ranges were used as representative of possible parental influence. Adult bird data were from the Msikaba Cape Vulture colony ( $31^{\circ} 16^{\prime} \mathrm{S}, 29^{\circ} 59^{\prime} \mathrm{E}$; Fig. 1) in the Mkambati Nature Reserve during the breeding season (Pfeiffer et al. 2015b). The Msikaba colony is located approximately $150 \mathrm{~km}$ from Colleywobbles. Although the data were not from the same colonies, given the colonies' proximity and their location in the former Transkei, similar results were expected.

The radii of the mean $99 \% \mathrm{KDE}(93 \mathrm{~km})$ and the mean $50 \% \mathrm{KDE}(46 \mathrm{~km})$ were taken as areas of potential parent influence. A 14-day period away from the natal home range was used as representative of independence. An individual was considered dispersed when it moved away from the adults' mean maximum ranging area $(93 \mathrm{~km})$ and did not return to the adults' mean core area $(46 \mathrm{~km})$ for the following 14 days (Pfeiffer et al. 2015b). Changes in distance over time were explored using a general linear model, with Day as a continuous variable and Individual as a fixed effect. To determine the relationship between Day and distance from the natal colony, four regression models (linear, quadratic, inverse, logarithmic) were fitted to the data to demonstrate the best fit. Statistical analyses were conducted in SPSS (IBM 2016).

\section{Habitat use}

Using the South African National Land Cover Database (South African National Biodiversity Institute 2014) amalgamated with the protected areas of South Africa and Lesotho (International Union for Conservation of Nature and United Nations Environmental Programmes World Conservation Monitoring Centre 2016), a land use map was created. Six land use classes were reclassified from the original 71 land use categories, namely commercial farmland, subsistence farmland, natural woody vegetation, tree plantations, urban centres and village communities, as per the method adapted from Pfeiffer et al. (2015b).

The pooled locations of fledgling's 99\% KDEs were clipped to the final reclassified land use map, excluding areas that extended beyond South African borders (Botswana, Lesotho), given limited vegetation maps. Within the 99\% $\mathrm{KDE}$, areas of all land uses were calculated (squared kilometres). GPS locations were considered the observed number of positions per habitat. Assuming individuals show no habitat preference, the expected number of GPS locations per habitat should be proportional to the amount of habitat within the
99\% KDE. Therefore, considering each land use separately, habitat use in proportion to habitat availability was tested with the $\chi^{2}$-test. Bonferroni confidence intervals, calculated in Microsoft Excel, were used to determine habitat use in proportion to habitat availability (Byers et al. 1984).

\section{Results}

\section{Home range}

The size of the $50 \% \operatorname{KDE}\left[r_{\mathrm{s}}(60)=0.173, P>0.05\right]$ was not correlated to the number of fixes, whilst the size of the $99 \%$ $\mathrm{KDE}\left[r_{\mathrm{s}}(60)=0.350, p<0.05\right]$ was correlated to number of fixes. Home range size of the five individuals did not differ significantly at the $50 \% \operatorname{KDE}(F=3.73, d f=4, p>0.05)$, but differed at the $99 \% \operatorname{KDE}(F=4.61, d f=4, p<0.05)$. A post hoc Tukey honest significant difference test showed that at the $99 \% \mathrm{KDE}$, the individuals Lunguza and Xobo differed significantly at $p<0.5$. Home range size between 14-day periods did differ significantly at the 50\% KDE $(F=16.06$, $d f=1, p<0.001)$ and the $99 \% \operatorname{KDE}(F=13.16, d f=1$, $p<0.001)$ as illustrated in Fig. 2. Cumulative home range size increased from a mean of $180 \mathrm{~km}^{2}\left(\mathrm{SD}=201.676 \mathrm{~km}^{2}\right)$ and $2228 \mathrm{~km}^{2}\left(\mathrm{SD}=2558.786 \mathrm{~km}^{2}\right)$ in the first 14 days to a mean cumulative home range of $36444 \mathrm{~km}^{2}(\mathrm{SD}=27$ $\left.168.59 \mathrm{~km}^{2}\right)$ and $287199 \mathrm{~km}^{2}\left(222,546.50 \mathrm{~km}^{2}\right)$ at 11 months for the 50 and 99\% KDEs (Fig. 3). During the PFDP the mean 50\% KDE and 99\% KDE were calculated as 986 and $14,363 \mathrm{~km}^{2}$, which translates to a core radius of $18 \mathrm{~km}$ and a home range radius of $68 \mathrm{~km}$, respectively.

\section{Dispersal}

The maximum net daily distance of each individual from the natal colony increased significantly $(F=200.11, p<0.001)$ over time. There was a noticeable increase in maximum net daily distance around 100 days (during April). Of the four regression models fitted to the data of the maximum daily distance from the colony of each individual, the $R^{2}$ quadratic regression was the best fit (Fig. 4). Fig. A1 illustrates dispersal movement once individuals were independent from parental influence.

\section{Habitat use}

Observed habitat use was not selected in proportion to expected habitat availability when the pooled $99 \% \mathrm{KDE}$ locations were used. Fledged Cape Vultures showed a preference for protected areas and woody vegetation (Table 3 ). Villages, urban areas, plantations, commercial farmland and subsistence farmland did not appear to be favourable habitat for juvenile Cape Vultures. 
Fig. 2 Mean size of the $50 \%$ kernel density estimate $(50 \% K D E)$ and $99 \%$ kernel density estimate $(99 \% K D E)$ home range $\left(\mathrm{km}^{2}\right)$ of five fledged Cape Vultures illustrated in 14-day intervals for the first 11 months
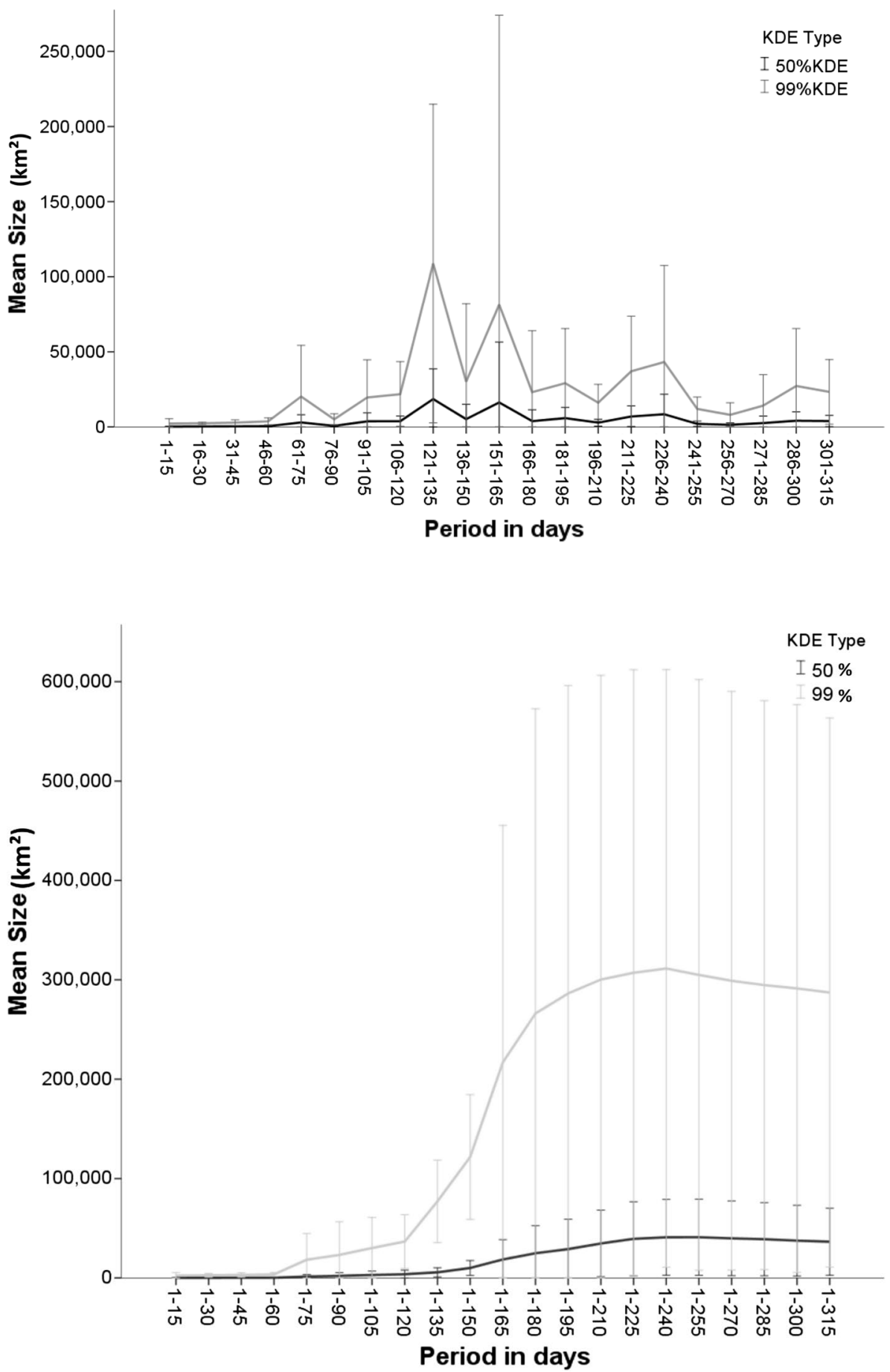

Fig. 3 Mean size of the 50\% KDE and 99\% KDE cumulative home range $\left(\mathrm{km}^{2}\right)$ of five fledged Cape Vultures for the first 11 months

\section{Discussion}

Detailed spatial movements of recently fledged Cape Vultures and their habitat use are provided in our study, which can aid in the conservation management of this species. Although the sample size is relatively small, it provides explicit information on the home range, PFDP, the onset of natal dispersal and the habitat use of these juvenile Cape
Vultures using accurate technological advances. Furthermore, it highlights the individual variation in movement and spatial use.

Home range sizes of newly fledged Cape Vulture individuals did not differ at the $50 \% \mathrm{KDE}$ but did differ at the 99\% KDE. This difference may be attributed to a single bird's flight up to Botswana, increasing the mean size of the 99\% KDE. Home range size increased progressively during the first 60 days, with a sudden increase of home range 

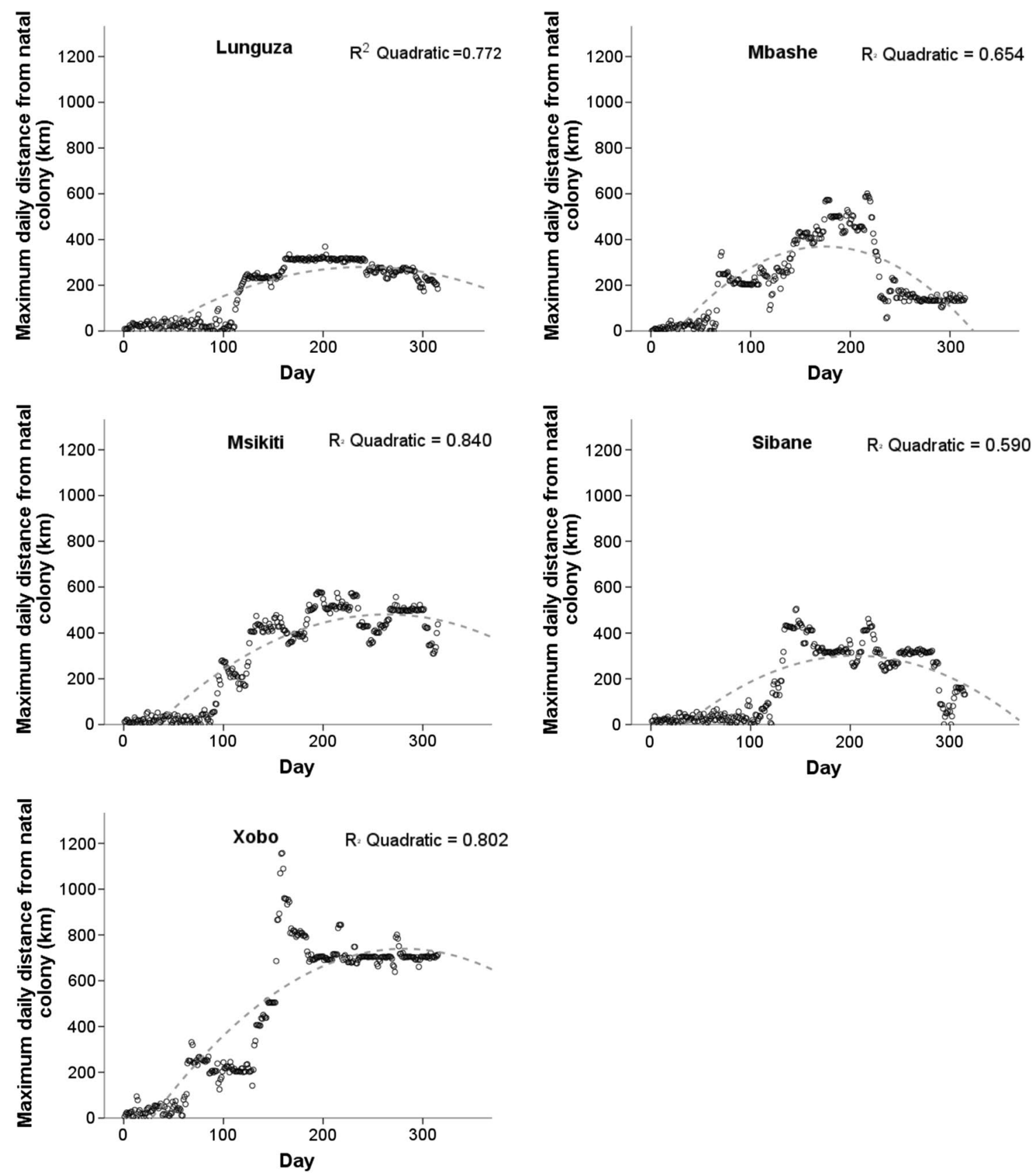

Fig. 4 Mean maximum net daily distance $(\mathrm{km})$ from the nest of five fledging Cape Vultures for 11 months with a quadratic curve fitted

size at 120 days. The areas traversed in this study by Cape Vulture fledglings are in the range of areas found in other studies of immature and first-year Cape Vultures (Phipps et al. 2013; Kane et al. 2016), whilst fledging Cape Vultures displayed larger areas than breeding and non-breeding adult birds (Pfeiffer et al. 2015b). Fledging Cape Vultures displayed a similar trend to Cinereous Vultures (Aegypius monachus) from Turkey, where the first 2 months were spent in close proximity to the natal area, after which time a gradual increase in home range size was observed as individuals moved further away (Yamaç and Bilgin 2012). The increase in home range size may be due to a number of reasons. Firstly, as individuals age, they may explore the surrounding territory, resulting in progressively larger home ranges. This has been observed in Bearded Vultures (Gypaetus barbatus) in the Maloti-Drakensberg, South Africa where home range size increased as individuals aged (Krüger et al. 2014). Secondly, juveniles may be outcompeted by more experienced adult birds for food sources around the colony, and consequently have to move further afield, resulting in larger 
Table 3 Pooled 99\% KDE habitat availability of fledged Cape Vultures based on the South African reclassified land use map

\begin{tabular}{lccllll}
\hline Habitat type & $\begin{array}{l}\text { Contribu- } \\
\text { tion }(\%)\end{array}$ & Area $\left(\mathrm{km}^{2}\right)$ & Pi & Pio & Bonferroni CI & Conclusion \\
\hline Protected area & 17 & 28374.00 & 0.301 & 0.174 & $0.281<P<0.321$ & Preferred \\
Village & 10 & 16823.29 & 0.012 & 0.103 & $0.008<P<0.017$ & Not preferred \\
Urban & 7 & 11491.08 & 0.002 & 0.071 & $0.000<P<0.005$ & Not preferred \\
Plantation & 8 & 13207.12 & 0.007 & 0.081 & $0.003<P<0.011$ & Not preferred \\
Woody vegetation & 5 & 8031.78 & 0.502 & 0.049 & $0.480<P<0.523$ & Preferred \\
Commercial farmland & 35 & 57085.08 & 0.136 & 0.350 & $0.121<P<0.151$ & Not preferred \\
Subsistence farmland & 17 & 27922.59 & 0.040 & 0.171 & $0.031<P<0.049$ & Not preferred \\
\hline
\end{tabular}

Bonferroni confidence intervals were used to determine Cape Vulture habitat use in $99 \%$ pooled KDE; Juvenile $=3778 ; Z, 2.69$

$\mathrm{Pi}$ Actual proportion of usage, Pio expected proportion of usage, $\mathrm{CI}$ confidence intervals home ranges (Mundy et al. 1992). Additionally, the increase of home range size around 120 days of fledging of Cape Vultures coincides with the subsequent breeding season of adult birds, during which time parental care and food provision to fledglings decreases, and as such the juveniles may have to move across the wider landscape (Mundy et al. 1992). The extensive range covered by fledging Cape Vultures provides evidence that fledged individuals wander far and wide in the landscape, as has been previously suggested (Piper 1994).

Fledgling birds experienced a mean PFDP of 101 days, and the distance from the nest increased after this period, as fledglings may no longer be dependent on their parents. The mean of the PFDP is similar to that of a Cape Vulture study from the Potberg Colony, Western Cape, South Africa (Robertson 1985) and Bearded Vultures of the Maloti-Drakensberg region of South Africa and Lesotho (Krüger and Amar 2017). Longer parental care of Old World vultures is expected given their body size, development of flight abilities and dependence on unpredictable food sources (Donázar and Ceballos 1990).

The mean maximum net daily distance from the natal colony remained relatively close to the colony in the first 100 days (Fig. 4), and this coincided with the PFDP experienced by the fledglings. Mean core area (50\% KDE) and mean home range (99\% KDE) size during the PFDP were 986 and $14,363 \mathrm{~km}^{2}$, which translates to a core radius and home range radius of 18 and $68 \mathrm{~km}$, respectively. Dispersal from the nest was apparent from 100 days onwards. This dispersal period of 100 days ( \pm 3 months) is slightly longer than that observed in Bearded Vultures from northern Spain (López-López et al. 2014) and Cinereous Vultures in Turkey (Yamaç and Bilgin 2012), which dispersed from the natal area within 2 months. It is evident that Cape Vulture fledglings remained in locations of similar distance from the colony for extended periods (as indicated by the points forming a straight horizontal line in Fig. 4). It is a possibility that areas where fledglings remained are nursery areas
(Mundy et al. 1992). Nursery areas are often established away from breeding colonies so as to minimise competition for scarce food resources with more competent adults, and have been observed in other species (Negro et al. 1997; Dwyer et al. 2010). It is therefore possible that fledglings move away from the colony, stay away from the colony for approximately 3 months, after which some individuals start returning to the natal colony (Fig. 4). This is in contrast to Piper et al. (1981) who stated that the Cape Vulture returns to the colony and potentially starts breeding at $4-5$ years.

Large ranging behaviours in fledged vultures have previously been speculated to be related to scarce food sources in the landscape and to avoid competition with more competent adults (Phipps et al. 2013). In terms of habitat use by fledged Cape Vultures, preference was given to protected areas and woody vegetation. The use of protected areas by fledglings may be linked to vultures' social foraging behaviour. Protected areas often contain adult vulture breeding colonies and feeding sites, and it is assumed that young birds use adults for learning, and thus follow adults to colonies and feeding sites. Protected areas predominately used by Cape Vultures (Table A1) in our study cover an extensive area of South Africa and cross a number of provincial borders, highlighting the need for provincial conservation agencies to collaborate to ensure similar management objectives are ascertained for this endangered species. The use of woody vegetation may be misrepresented, as suggested by Pfeiffer et al. (2015b). Cliffs located above woody vegetation may have been used as roosting sites, yet may have been misrepresented as woody vegetation based on the forested areas generally located below cliffs. It is interesting to note that areas of subsistence farmland were not preferred, as was speculated. Adult birds used subsistence farmland during both the breeding and non-breeding season (Pfeiffer et al. 2015b), which differs to fledglings, which showed no preference for subsistence farmland. This may support the theory that young birds are inexperienced feeders and are pushed 
out (through competitive interactions for food sources) to marginal forage areas, e.g. commercial farmland, as has been observed in Bearded Vultures (Krüger et al. 2014).

It is evident that fledged Cape Vultures range over a vast area and this is a challenge in terms of conservation management. The use of protected areas by fledged Cape Vultures bodes well for management, and further conservation effort can be focused on protected areas well utilised by these young birds. The mean radius of the core area of fledglings during their PFDP falls within the recommended conservation buffer zones ( $35 \mathrm{~km}$ for roosts, $40 \mathrm{~km}$ for breeding colonies, $55 \mathrm{~km}$ for feeding sites) (Pfeiffer et al., in review) surrounding breeding colonies, thus highlights the significance of these buffers not only protecting breeding birds, but also young, inexperienced vultures. Further research may be warranted to identify nursery areas and identify management strategies for these areas. Although the study period was limited in days, it illustrated that fledglings move away from the colony, remain away for a number of months and may eventually return to the natal colony. Whether fledglings will remain in their natal colony or move away from it again requires further research.

With fledged Cape Vultures ranging over a far wider landscape, they face a variety of threats due to their inexperience when compared to adult birds. With a loss of three of eight fledgling birds fitted with trackers as a result of power lines, it is important to identify the movement and habitat use of fledglings to create an effective tool for conservation planning. By identifying such parameters, conservation efforts can focus on power line mitigation, anti-poisoning events, locations of suitable feeding sites and areas of potentially high wind energy development (which is an emerging threat to these endangered birds), such as the Eastern Cape Province, South Africa.

Acknowledgements The Endangered Wildlife Trust are thanked for providing the necessary training and equipment. Thomas River Conservancy, P. Miles, R. and K. Wardle, H. and M. Neethling and Eskom are thanked for assistance, especially with housing, during fieldwork. H. Payne, T. Caine, V. Thabethe, C. Fritsch, M. Small, P. Gibson, J. Greef, B. Hoffman, S. McPherson, A. Bowe, B. DePreez, D. Mafuso, A. Harvey, R. Stretto, K. Lindner, T. van der Meer, P. Singh, M. Drabik-Hamshare and the community of Colleywobbles are thanked for their assistance with fieldwork. The Rufford Foundation, Gay Langmuir bursary, BirdLife South Africa, National Research Foundation, A. and M. Jooste, Fairfield Tours, Eastern Cape Parks and Tourism Agency, Eastern Cape Department of Economic Development, Environmental Affairs and Tourism, Nelson Mandela University and the University of KwaZulu-Natal provided financial support. We thank the reviewers for their comments, which greatly improved the manuscript.

\section{Compliance with ethical standards}

Conflict of interest The authors declare that they have no conflict of interest.
Ethical approval All applicable international, national, and/or institutional guidelines for the care and use of animals were followed. The procedures were approved by the University of KwaZulu-Natal Ethics Committee. Permits for the capture and handling of vultures and the fitting of tracking devices were granted by the Department of Environmental Affairs through the Threatened or Protected Species permit (permit number:29551).

\section{References}

Allan D (2015) A conservation assessment of Gyps coprotheres species. In: Taylor M, Peacock F, Wanless R (eds) The Eskom Red Data Book of Birds of South Africa, Lesotho and Swaziland. BirdLife South Africa, Johannesburg

BirdLife International (2015) Gyps coprotheres. The IUCN Red List of Threatened Species 2015. http://dx.doi.org/10.2305/IUCN. UK.2015

BirdLife South Africa (2015) Colleywobbles Vulture Colony. http:// www.birdlife.org.za/get-involved/join-birdlife-south-africa/ item/230-sa088-collywobbles-vulture-colony. Accessed: 6 June 2017

Boshoff A, Minnie J (2011) On the role of the shape and size of foraging area, and colony size, in selecting critical areas for Cape Griffon Gyps coprotheres conservation action. Vulture News 61:4-15. https://doi.org/10.4314/vulnew.v61i1.1

Boshoff AF, Piper S, Michael M (2010) On the distribution and breeding status of the Cape Griffon Gyps coprotheres in the Eastern Cape Province, South Africa. Ostrich 80:85-92. https://doi. org/10.2989/ostrich.2009.80.2.4.831

Brown C, Piper S (1988) Status of Cape Vultures in the Natal Drakensberg and their cliff site selection. Ostrich 59:126-136. https:// doi.org/10.1080/00306525.1988.9633714

Byers CR, Steinhorst RK, Krausman PR (1984) Clarification of a technique for analysis of utilization-availability data. J Wildl Manage 48:1050-1053. https://doi.org/10.2307/3801467

Delgado MM, Penteriani V, Nams VO (2009a) How fledglings explore surroundings from fledging to dispersal. A case study with Eagle Owls Bubo bubo. Ardea 97:7-15. https://doi. org/10.5253/078.097.0102

Delgado MM, Penteriani V, Nams VO, Campioni L (2009b) Changes of movement patterns from early dispersal to settlement. Behav Ecol Sociobiol 64:35-43. https://doi.org/10.1007/s00265-009-0815-5

Donázar JA, Ceballos O (1990) Post-fledging dependence period and development of flight and foraging behaviour in the Egyptian Vulture Neophron percnopterus. Ardea 78:387-394

Dwyer JF (2010) Ecology of non-breeding and breeding Crested Caracaras (Caracara cheriway) in Florida. PhD thesis, Virginia Polytechnic Institute and State University

Gilbert M, Virani MZ, Watson RT, Oaks JL, Benson PC, Khan AA, Ahmed S, Chaudhry J, Arshad M, Mahmood S, Shah QA (2002) Breeding and mortality of Oriental White-backed Vulture Gyps bengalensis in Punjab Province. Pakistan Bird Conserv Int 12:311-326. https://doi.org/10.1017/s0959270902002198

Harel R, Horvitz N, Nathan R (2016) Adult vultures outperform juveniles in challenging thermal soaring conditions. Sci Rep 6:27865. https://doi.org/10.1038/srep27865

IBM Corp (2016) IBM SPSS statistics for Windows, version 24.0. IBM, Armonk

International Union for Conservation of Nature and Natural Resources and United Nations Environment Programme's World Conservation Monitoring Centre (UNEP-WCMC) (2016) The World 
Database on Protected Areas (WDPA). UNEP-WCMC, Cambridge, UK. http://www.protectedplanet.net

Johnson MD (2007) Measuring habitat quality: a review. Condor 109:489-504. https://doi.org/10.1650/8347.1

Kane A, Wolter K, Neser W, Kotze A, Naidoo V, Monadjem A (2016) Home range and habitat selection of Cape Vultures Gyps coprotheres in relation to supplementary feeding. Bird Study 63:387-394. https://doi.org/10.1080/00063657.2016.1214105

Krüger S, Amar A (2017) Insights into post-fledging dispersal of Bearded Vultures Gypaetus barbatus in southern Africa from GPS satellite telemetry. Bird Study 64:125-131. https://doi. org/10.1080/00063657.2017.1295019

Krüger S, Reid T, Amar A (2014) Differential range use between age classes of Southern African Bearded Vultures Gypaetus barbatus. PLoS One 9:e114920. https://doi.org/10.1371/journal.pone.01149 20

Laver PN, Kelly MJ (2008) A critical review of home range studies. J Wildl Manage 72:290-298. https://doi.org/10.2193/2005-589

López-López P, Garcìa-Ripollés C, Urios V (2014) Food predictability determines space use of endangered vultures: implications for management of supplementary feeding. Ecol Appl 24:938-949. https://doi.org/10.1890/13-2000.1

Loss SR, Will T, Marra PP (2015) Direct mortality of birds from anthropogenic causes. Annu Rev Ecol Evol Syst 46:99-120. https ://doi.org/10.1146/annurev-ecolsys-112414-054133

McFadzen ME, Marzluff JM (1996) Mortality of Prairie Falcons during the fledging-dependence period. Condor 98:791-800. https://doi. org/10.2307/1369859

Morrison JL, Wood PB (2009) Broadening our approaches to studying dispersal in raptors. J Raptor Res 43:81-89. https://doi. org/10.3356/jrr-08-33.1

Mundy P, Butchart D, Ledger J, Piper S (1992) The vultures of Africa. Acorn, Randburg

Negro JJ, Hiraldo F, Donázar JA (1997) Causes of natal dispersal in the Lesser Kestrel: inbreeding avoidance or resource competition? J Anim Ecol 66:640-648. https://doi.org/10.2307/5917

Ogada DL, Keesing F, Virani MZ (2012) Dropping dead: causes and consequences of vulture population declines worldwide. Ann N Y Acad Sci 1249:57-71. https://doi.org/10.111 1/j.1749-6632.2011.06293.x

Péron C, Grémillet D (2013) Tracking through life stages: adult, immature and juvenile autumn migration in a long-lived seabird. PLoS One 8:e72713. https://doi.org/10.1371/journal.pone.0072713

Pfeiffer MB, Venter JA, Downs CT (2015a) Identifying anthropogenic threats to Cape Vultures Gyps coprotheres using community perceptions in communal farmland, Eastern Cape Province, South Africa. Bird Conserv Int 25:353-365. https://doi.org/10.1017/ s0959270914000148

Pfeiffer MB, Venter JA, Downs CT (2015b) Foraging range and habitat use by Cape Vulture Gyps coprotheres from the Msikaba colony,
Eastern Cape Province, South Africa. Koedoe 57:1-11. https:// doi.org/10.4102/koedoe.v57i1.1240

Pfeiffer MB, Venter JA, Downs CT (2017) Observations of microtrash ingestion in Cape Vultures in the Eastern Cape. South Africa African Zool 52:65-67. https://doi.org/10.1080/15627020.2016.12701 72

Phipps WL, Wolter K, Michael MD, MacTavish LM, Yarnell RW (2013) Do power lines and protected areas present a catch-22 situation for Cape Vultures (Gyps coprotheres)? PLoS One 8:e76794. https://doi.org/10.1371/annotation/f4701461-4b42-4744-83380c15c9065800

Piper S (1994) Mathematical demography of the Cape Vulture. PhD thesis, University of Cape Town

Piper SE, Mundy PJ, Ledger JA (1981) Estimates of survival in the Cape Vulture, Gyps coprotheres. J Anim Ecol 50:815-825. https ://doi.org/10.2307/4139

Piper SE, Mundy PJ, Vernon CJ (1989) An ageing guide for the Cape Vulture. Modoqua 16:105-110

R Core Team (2016) R: a language and environment for statistical computing. R Foundation for Statistical Computing, Vieanna. URL https://www.R-project.org/

Robertson AS (1985) Observations on the post-fledging dependence period of Cape Vultures. Ostrich 56:58-66. https://doi. org/10.1080/00306525.1985.9639570

Sandgren C, Hipkiss T, Dettki H, Ecke F (2014) Habitat use and ranging behaviour of juvenile Golden Eagles Aquila chrysaetos within natal home ranges in boreal Sweden. Bird Study 61:9-16. https:// doi.org/10.1080/00063657.2013.857387

Signer J, Balkenhol N (2015) Reproducible home ranges ( $r h r)$ : a new, user-friendly R package for analyses of wildlife telemetry data. Wildl Soc Bull 39:358-363. https://doi.org/10.1002/wsb.539

South African National Botanical Institute (SANBI) (2014) National land cover database. SANBI, Pretoria, South Africa

Todd LD, Poulin RG, Wellicome TI, Brigham RM (2003) Post-fledging survival of Burrowing Owls in Saskatchewan. J Wildl Manage 67:512-519. https://doi.org/10.2307/3802709

Vernon CJ (1998) The Cape Vulture at Colleywobbles: 19771997. Ostrich 70:200-202. https://doi.org/10.1080/00306 525.1999 .9634236

Weston ED, Whitfield DP, Travis JMJ, Lambin X (2013) When do young birds disperse? Tests from studies of Golden Eagles in Scotland. BMC Ecol. https://doi.org/10.1186/1472-6785-13-42

Wiens JD, Noon BR, Reynolds RT (2006) Post-fledging survival of Northern Goshawks: the importance of prey abundance, weather, and dispersal. Ecol Appl 16:406-418. https://doi. org/10.1890/04-1915

Yamaç E, Bilgin CC (2012) Post-fledging movements of Cinereous Vultures Aegypius monachus in Turkey revealed by GPS telemetry. Ardea 100:149-156. https://doi.org/10.5253/078.100.0206

\section{Affiliations}

\section{Francis R. Martens ${ }^{1} \cdot$ Morgan B. Pfeiffer $^{1,2,3} \cdot$ Colleen T. Downs $^{3} \cdot$ Jan A. Venter ${ }^{1}$ (D)}

Jan A. Venter

jan.venter@mandela.ac.za

1 School of Natural Resource Management, George Campus, Nelson Mandela University, George, Madiba Drive, George 6529, South Africa

2 US Department of Agriculture, Animal and Plant Health Inspection Service, Wildlife Services, National Wildlife
Research Center, Ohio Field Station, 6100 Columbus Avenue, Sandusky, OH 44870, USA

3 School of Life Sciences, University of KwaZulu-Natal, Private Bag X01, Scottsville, Pietermaritzburg, KwaZulu-Natal 3209, South Africa 